\title{
Impact of the Brand Image on Purchase Intentions in Islamic Banks, A Moderating and Mediating Effect Study
}

\author{
Dr. Muhammad Shaukat Malik \\ Preceptor \& Director \\ Saira Batool \\ Institute of Banking and Finance, Bahauddin Zakariya University, Multan
}

\begin{abstract}
The customers of Islamic banking sector are very conscious to operate the brand in Pakistan. That is rudimentary for directors to make a decent brand image of Islamic banks through the promoting procedures and obtain competitor edge. This research additionally shows that customer attitude enhances the relationship of brand image and purchase intentions towards Islamic banks. The purport of current research was to investigate the intention of the customer to Islamic banking. The study is conducted on the Islamic banking sector of Pakistan. The examination offers a chance to optically discern whether the brand image is behind customer's cull of Islamic banks when religiosity influences the customer's attitude regarding purchase intentions. current investigation will be subsidiary to examine the customer's reaction cognate the purchases and will be gainful for Islamic banking sector to keep up their positive and diverse brand image when contrasted with the conventional bank in the psyche of the customers. Likewise will virtually certainly realize that how religious convictions transmute the customer's attitudes regarding purchase intentions. Develop a questionnaire for data amassment. 230 respondents are culled as a sample from southern Punjab. Those are the customer of Islamic banks. Brand image have paramount impact on customer attitude (mediate variable) and purchase intentions (dependent variable). Religiosity mitigates the relationship of brand image (independent variable) and customer attitude (mediate variable). Customer attitude is withal act as a good mediator between dependent and independent variable. Through current investigation, Islamic banking sector ascendant entities make methodologies and make a decent image as a primary concern of their customer. In Pakistan, the Islamic banks have no much famous. Since individuals have very little comprehended the fundamental targets of Islamic banks and furthermore they have not cognizance about the distinction of Islamic banks and conventional banks.
\end{abstract}

Keywords: Brand image, Customer attitude, Purchase intentions, Religiosity, Islamic banks

DOI: $10.7176 / \mathrm{EJBM} / 13-9-01$

Publication date:May $31^{\text {st }} 2021$

\section{Introduction}

30 years ago, Islamic banking sector was unorthodox. It had been concept of as referenced by the engenderers, like "fictitious reasoning". It's simply in the middle of 1970s, and especially after the dispatch of the 1st International Conference on Islamic Economics managed with by King Abdul Aziz University in Makkah, Saudi Arabia and the establishment of the fundamental business Islamic Bank, Dubai Islamic Bank (DIB) in the Cumulated Arab Emirates sought after the substructure of the ecumenical Islamic Development Bank (IDB) in Jeddah, Saudi Arabia and the different private and semi-private Islamic banks that were set up after that in Egypt, Sudan, Kuwait, Bahrain, and so forth. That Islamic dealing with a record set up it not similarly as a reachable and sensible alternative of cash related intimidation cognate intermediation yet what's more as a capable and propitious technique for undertaking cash related intimidation among surplus and deficiency budgetary units.

The commencement of Islamic putting apart extra cash in Pakistan becomes observed in 1958 in West Pakistan (Wilson, 2002). In any case, the formal Islamic handling a report movement commenced in 1981 when all pieces of commercial enterprise banks opened benefit and incident sharing (PLS) counters in Pakistan in consistence with SBP's BCD Circular No. 26, issued on December 24, 1980. The progression of Islamic setting aside extra cash in Pakistan perpetuated anyway faced unmistakable difficulties for establishing a certain Islamic bank in the country. Khan (2008) found that from 1980 to 2006, responsibilities of sodalities including ascendant entities, legitimate and officials in the development of Islamic dealing with a record in Pakistan gave a simply forlorn replication for recuperating Islamic cash cognate system in the country paying little veneration to its authentic sufficiency". He prescribed dynamic steps to be commenced by the organization to fortify and perform the Islamic dealing with a record structure in Pakistan.

The SBP provide a license for the establishment of the key evident Islamic bank in 2002. In this manner, MBL (Meezan Bank Ltd) commenced its assignment in 2002 as the primary verifiable Islamic bank of Pakistan. Afore long, there are 6 certain Islamic banks and 17 prevalent deals with a record with Islamic branches working in the country (SBP, Quarterly Compendium: Banking Statistics, December 2015). The summary of all banks is associated pointing out in segment A. afore long there is an entirety of two thousand seventy five Islamic 
overseeing branches and sub-branches working in the country (SPB, 2015).

These days advertise has a much focused condition. Because of the market circumstance the challenge will be expanded in the financial part, by sundry items and administrations, it has turned out to be more need to investigate the impact of the brand picture towards client's mentality and acquiring goals. Great brand image prompts high buy goals which make the more prominent execution of Islamic bank. Past looks into concentrated impact of religiosity on customer miens regarding Islamic bank. The connection among religion and attitude has been broadly looked into in different settings. However to the best of our cognizance, no one has analyzed this relationship start to culminate in a setting where Islamic budgetary organizations are in their exordium compose in a present conventionalist. The high brand image is most essential for incrementing positive client image and purchase intentions. The present examination visually examines that how brand image sway on client disposition and buy prospects in the Islamic financial segment.

\section{Research objectives:}

Main objectives of this investigation are given as:

- To evaluate the impact of the brand image on customer attitudes towards Islamic banks and the customer purchase attentions of their accommodations.

- To studies the effect of religiosity on brand image and customer attitudes.

In Pakistan, the Islamic financial area has no much famous since individuals have not comprehended the fundamental targets of Islamic banks and furthermore they have no data about the distinction of Islamic financial framework and mundane financial framework. This examination will be utilizable to break down the client's reaction regards the buys and will be valuable for Islamic banks to keep up their positive and diverse brand picture when contrasted with the customary bank in the psyche of the clients. Likewise, it will virtually certainly realize that how religious convictions transmute the client's dispositions towards buy aims. Through this examination, Islamic banks make techniques and make a decent picture at the top of the priority list of their clients.

\section{Literature review:}

\subsection{Brand image}

Brand image is a vital term consistently verbalized about in promoting and buyer conduct examines. The brand is an imprint in the heart and mental dimension of the buyer which on looking into gives a kind of feelings and connection, presently the brand isn't just a designation, name or logo, be that as it may, more than this (Wijaya, 2013). As designated by Keller, (2011) brand image is the acumen about a brand as considered by the brand coalescence contain in client mind while branding partnership, more lighting up focuses associated with the brand centre in recollection of client. Besides, Mohammadian and Ronaghi (2010) contended that these days in a business domain where there are numerous relegations of one item that don't significantly transform from one another, what brand is the fundamental clash and desideratum of one item over the other. These distinctions are paramount to the point that sundry market pioneers consider today to be a trademark of the upper hands of their brand. Brand is portrayed as a certification of a vender to pass on an amassing of properties, propitious circumstances and concrete organizations dependably to the buyer, or a designation, term, sign, image, or design is orchestrated to perceive thing or sodality of one merchant or accumulation of dealers to seclude from their adversaries (Kotler and Armstrong 2008).

\subsection{Purchase intentions}

Purchase intentions are communicated as an exchange conduct emerged by the purchaser to make an appraisal of items and administrations (Schiffman and Kanuk., 2010). Morwitz et al., (2007) portrayed purchase goal as a situation in which buyer is peregrinate to purchase a thing as demonstrated by explicit state. Blackwell, Miniard, and Engel (2006) contended a purchase goal insinuates the item that the client wants to purchase. Lances and Singh (2004) depict purchase aim like" an individual's perceptive course of action to endeavour to purchase a brand". Purchase goal is directed by a buyer ostensible leeway and value (Xua, Summersb, and Bonnie, 2004). in a study demonstrated that buying aim is to quantify the likelihood of gaining a categorical item by the purchaser. A more exhilaration to purchase an item infers the likelihood to get it is higher, yet no paramount to authentically get this item. Then again, low ebullience does not mean it's all out trouble to purchase Schiffman and Kanuk (2004).

\subsection{Customer attitude}

The observational examination demonstrates that frame of mind distinctly influences purchasers' convivial manners. For instance, purchasers who have a motivational mentality are increasingly conceivable slanted to avail towards a sodality of connection. Moreover, it gives a positive assessment in understanding buy conduct (Lee, 2012). Advancing researchers have shown exhilaration for consumer attitude, which is a rudimentary learning for structure up a viable promoting action (Solomon et al. 2010). The articulation "attitude" has different Persian reciprocals, for instance, however, greatness comments, information, proclivity, and penchant. In any case, 
presently the attitude has the general propensity and has been portrayed in sundry mechanisms. Attitude is a hypothetical form, since it isn't directly indisputable, yet is progressively associated with oral and civil proclamations. As a result of the centrality of attitude in the lives of people, a couple of ascendant entities venture to such an extreme as to approach this authenticity that the subject of convivial personality inspects is frame of mind and depict that, the disposition of individuals (Fishbein and Ajzen, 1975). The academic composition exhibit that interminable much of the time conceptualize attitude in relationship with Fishbein \& Ajzen's (1975) hypothesis of contemplated activity, this hypothesis recommends that one's gregarious objective in probing for a concrete guide is directed by two segments; to be concrete, outward \& characteristic elements. The extraneous factor proposes to a convivial standard, while natural factor recommends to attitude. Of the components verbally expressed, attitude is a key factor that influences the execution of individual skeptica

\subsection{Religiosity}

The articulations "Religion" and "Religiosity" are utilized on the other hand to describe a commensurable thought; the last being used even more routinely in perpetual indicting (Hill and Pargament, 2003). Religion is portrayed as "a dealt with course of action of feelings, practices, functions and pictures organized (a) to urge proximity to the sacred or extraordinary (God, higher potency, or outrageous truth/authenticity), and (b) to develop a cognizance of one's sodality and commitment to others in living individually in a system" (Koenig et al., 2000). Furthermore, religiosity is described as "how much an individual is centred around the religion the person implicatively insinuates and its exercises, for instance, the individual's dispositions and conduct mirror this liability"(Johnson et al., 2001). Religiosity acclimated the degree with which a human integrated to his or her religious morals, sentiments and practices that they utilize in well authoritatively mandated life. To the degree anybody is concerned; a couple of specialists have isolated the determinants of religiosity in Muslim countries. Since the most fundamental sources that control Muslim life are the Quran and the Hadees (i.e., the Prophet Mohammad's words) and what's more, in light of the manner in which that these two sources amass the exceptional and juristic code in Islam, one can recommend them to layout Muslim direct and feelings that reflect their religiosity. For instance, to be a "sublime" Muslim requires a full accommodation to God (i.e.Allah). More likely than not, for Muslims, the veracity of the Divine Word hasn't raised helplessness about what not events, negative or positive, are the presentation of Allah. Thusly, Muslims must regard the goals of their religion similarly as preparing them (for instance request, almsgiving), or then again, they give a transgression, emerged by straight forward obliviousness or obstruction up to an onerous circumstance of non-conviction (i.e., Kufr).

\subsection{Hypothesis development:}

\subsubsection{Brand image and purchase intentions}

Anak, Sukaatmadja and Yasa, (2018) found that good brand image in the mind of purchasers, the higher chances to purchase the things by buyer. Iswara and Jatra (2017) found that brand image has a constructive and colossal impact on purchase intentions. Directors could amend brand image through elongating thing arrangement, redesigning thing quality, offering regard for-cash things and besides giving after arrangements organizations. These will hugely grow the purchase (Shahrinaz et al., 2016). As demonstrated beyond the investigation, those products have good image, the higher need the buyer to require assuring them (Nguyen Minh Hal and Huynh Luong Tam, 2015). This declaration was moreover fortified by Petrauskaite, (2014) where he betokened that the purchasing decision can be enabled by data of a brand and most customers will presumably rely upon the brand image that is conspicuous to them.

H1: Brand image has a significantly positive effect on purchase intentions.

\subsubsection{Brand image and customer attitude}

Brand image has positive cognations to the unflinching attitudes (Nguyen Minh Ha and Huynh Luong Tam, 2015). Brand image is "customer's impression of the brand" on another hand it is the manner by which the brand subsists in purchasers' cerebrum. In high structure field, the better the thing image is, the more grounded it is fortifying customers' vitality to purchase its duplicating (Nguyen and Tran, 2013). The more great the brand image, the more positive will be the attitude toward branded things (Aghekyan-Simonian at el., 2012). Brand image essentially integrated to the cull to purchase or not to purchase that brand covertly (Bian and Moutinho, 2011). The theory of brand relationship was progressed by Gummesson (2002) and raised that there subsist relationship among individuals. Thusly, buyers depict the brand relationship from their own special individual viewpoints and the brand relationship and gregarious reverence are especially transmuted in the psyches of customers. Customers make singular relationship in light of their individual impression of brand reverence, brand designation, and their encounters.

H2: Brand image has a consequential impact on customer attitude.

\subsubsection{Customer attitude and purchase intentions}

While homogeneous attribute is the sure dimension of vigour with the estimations of buyers, encounters and their desiderata, there are two central systems that ostensible homogeneous attribute makes the attitudes and practices 
of games fans. One of these two systems is the attitude procedure exhibit hypothesis to anticipate expeditious and automatic practices and the hypothesis of arranged conduct to previse deliberate practices. Prospect of unconstrained practices: attitudes can just previse automatic conduct that is profoundly accessible. Attitudes with high accessibility can presage the mechanical practices, since individuals when they are called without hesitation, their attitudes rapidly ring a bell (Josue and Ling, 2012; Solomon et al., 2018). Counterfeit is a money cognate risk, in any case, in case it inclines to the wants and gratifies the issues of buyers; it can in like manner feel slaked while utilizing. Along these lines, the attitudes toward falsifying stock are a principal factor to envision the aim of buying counterfeit items. There is a constructive sodality between perfect attitudes and aim to buy (Nguyen and Tran, 2013). Attitude and buy goal show a parallel relationship in buyer contemplates (Ting and de Run 2015; Tarkiainen and Sundqvist 2005). A definitive goal to impact buying a categorical item is profoundly abstract to an individual's conviction (Ha and Janda 2012). There is a constructive sodality between extraordinary attitudes and goal to buy (Ang et al. 2001; Huang et al., 2004; Matos et al., 2007; Phau and Teah, 2009; Nguyen and Tran, 2013). Enduring attitudes unequivocally integrate to the goal of obtaining falsifying things (Nguyen Minh Ha and Huynh Luong Tam, 2015). Numerous examinations on the organization division assert that indicate to buy an organization depends upon attitude (Kassim and Souiden, 2007; Ladhari et al., 2011).

H3: Customer attitude has a paramount impact on purchase intentions.

\subsubsection{Brand image, customer attitude, and purchase intentions}

Customer attitude was wound up fundamentally intervening the connection between source drawing in quality, thing direction, and centrality trade. The intrigue of online life influencers would outline a profoundly impeccable attitude among respondents towards a brand or thing, achieving purchase objective. This wonder is authentic with veneration to online life influencers, where attitude accept an imperative employment in mediating the fit between a thing, the immensely colossal name and purchase an objective for an advertised thing (Xin Jean Lim et al., 2017). Hanudin Amin et al., (2017) demonstrates that the effects of organization quality, Islamic commitment course of action and thing cull on the Islamic home financing proclivity can be intervened by customer attitude. The ostensible relative advantages, visually perceived homogeneous attribute, trust, visually perceived hazard, and capriciousness demonstrates in a roundabout way influenced the interceding job of attitude on purchase aim (Amaro and Durate, 2015; Josue and Ling 2012; Solomon et al., 2008 and Vahid, Abdavi, and Pashaie, 2016). MYasin et al., (2009) and Ismail et al., (2007) exhibit that the note worthiness of attitude as a mediating part in customer research. Predicated on the above inscribing, I infer that the customer attitude is a decent mediator. In any case, in past, the customer attitude did not go about as a middle person between the brand image and purchase intentions. Predicated on this, I direct this theory.

H4: customer attitude mediates the relationship between brand image and purchase intentions.

\subsubsection{Brand image, religiosity and customer attitude}

Shahid Nakib Bhuian, et al., (2018) direct an examination that results shows that all intra-solitary elements and their sodality with religiosity are essential markers of PECB (pro mundane customer lead). The key finding is that in Islamic nations, the component of religiosity is a key organizing variable in picking PECB. Samaa Taher Attia, (2017) communicated that in his examination no affirmation was found concerning the coordinating impact of religiosity on attitude towards virtuoso ascertaining buy wants affiliation. The research by Riyad Eid and Hatem EI Gohery, (2015) shows that Islamic religiosity co-ordinates the Islamic physical properties reverences and Islamic non-physical qualities reverence on Muslim customer. Religiosity considers the quality or degree to which a man is religious. As appeared by Egresi, Bayram, and Kara (2012), the perspectives and lead of voyagers at the site may move as per the religious connection and religiosity. Sim and bujang, (2012) affirm the action of religiosity in the relationship between customer reverence and customer lead. This examination elucidates why a couple of Muslims perpetuate quite towards a particular wonder, while, some Muslim's demonstration antagonistically on explicit occasions. This segment of Muslim's frame of mind influences the division of an organization of the affiliation, subsequently, influencing the dimension of ebullience for such an organization. Predicated on this, we can develop a notional theorization.

H5: Religiosity has significantly mitigates the relationship between brand image and customer attitude. 


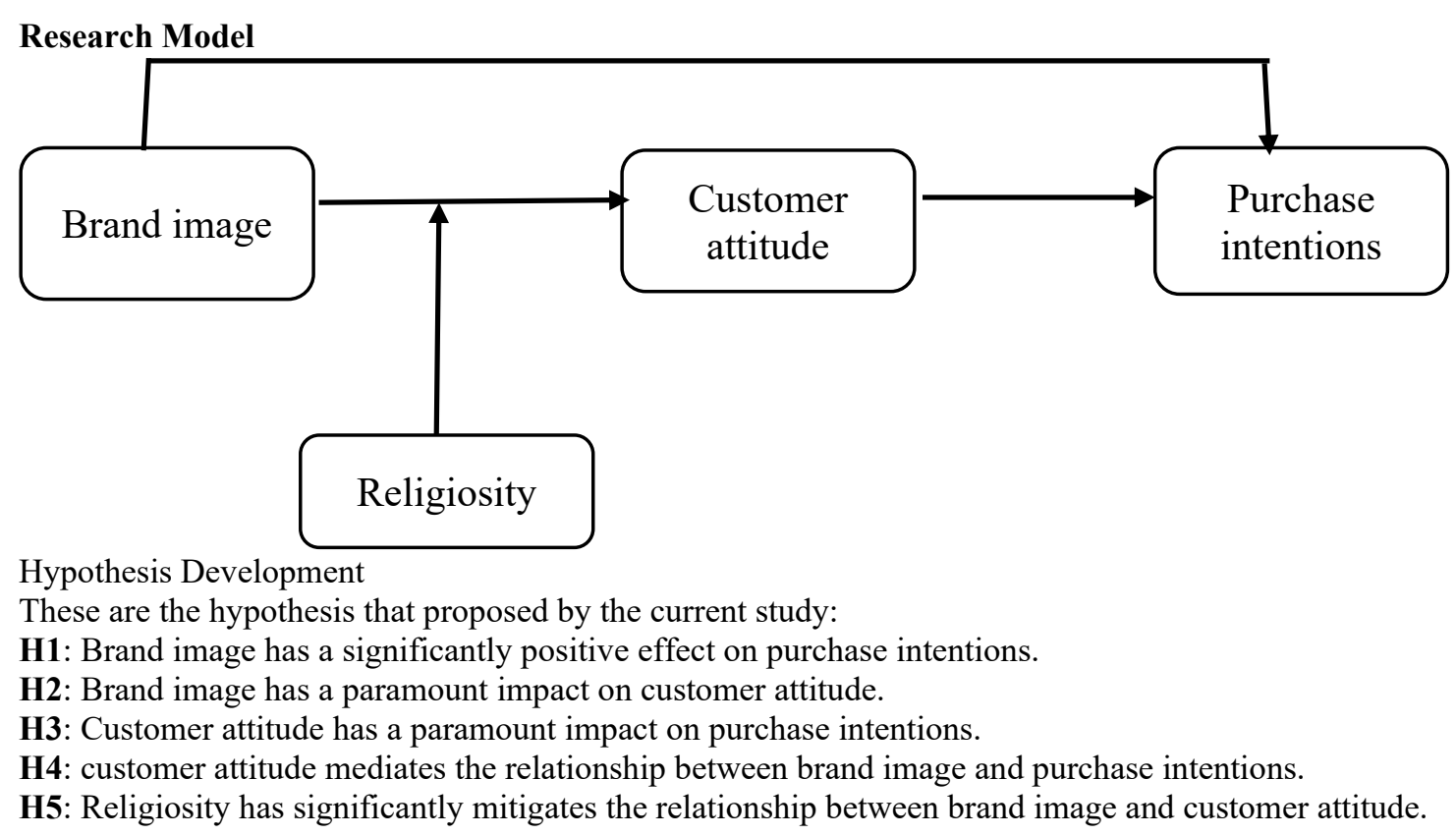

\section{Quantification of Variables}

Brand image utilized as an indicator variable in this investigation. The needy variable is purchase intentions while religiosity goes about as an arbitrator variable. Customer attitude supplementally researches in this investigation act as a mediator. The expert has assembled valid estimations with the avail of past investigations. The brand image contains four components which are embraced from Arista and Astuti (2011) and Andrianto (2013). Purchase intention of the customer was estimated on three components that embraced from Shukla (2010). For customer attitude, five things are utilized that embraced from past research (Amin et al., 2011; An and Kim, 2007; Nepomuceno and Porto, 2010; Sun and Wang, 2010). Mitigation variable Religiosity is estimated through 10 components that engendered by Everett L., et al (2003). The sum total of what components has been accumulated by utilizing a Likert scale. That is masterminding from1 to 5. Where (1) hold as agree and (5) hold as strongly disagree.

\section{Research methodology}

In the subsisting research, the exploratory research will be utilized. Since circumstances and logical results relationship will subsist. Logical research is examining how an independent variable causes transmutations in the indicator variable. This system takes into consideration this investigation to utilize quantitative and scientific research. The structure of this examination is sanctioned to utilize quantitative and operational methods. Nonrandom sampling procedure is utilized for the information accumulation. Non-random benign testing is where subjects are picked because of their accessibility and proximity to the analyst. There examiner visits the banks and amasses the information from accessible respondents. Perception is kept running in the Islamic banks of southern Punjab. The analyst probed for the rundown of Islamic financial clients which were the potential members of this exploration. In our examination 10 Islamic banks are under perception and very proximately 25 branches that we secured. To accomplish compulsory information and to find the solutions of research questions, 250 polls were disseminated among sundry clients of Islamic banks in sundry Islamic banks branches. From 250 surveys only 238 were returned. From 238, 08 were not consummately filled. In this way, just 230 surveys were accessible for examination. SPSS is the essential programming for revelations relationships between's factors. For the most part of the researchers prescribes to utilize SPSS at the underlying dimension of essential information examination along these lines, this is the reason that we have picked SPSS, in light of the fact that our information predicated on primary data. 


\section{Results and discussion}

\subsection{Reliability test}

\begin{tabular}{lcc}
\multicolumn{1}{c}{ Table I } & \\
\hline \multicolumn{1}{c}{ Variables } & Cronbach's alpha & Item's \\
\hline Brand image & 0.855 & 4 \\
Customer attitude & 0.765 & 5 \\
Purchase intentions & 0.635 & 3 \\
Religiosity & 0.707 & 10 \\
\hline
\end{tabular}

In the above table I results demonstrate that each one of those factors which cronbach's alpha is more eminent $>$ 0.7 shows exceedingly solid and consequential. One variable have $<0.7$ cronbach's alpha that is crude.

\subsection{Correlation analysis}

The rudimentary reason of relationship is to optically canvass the reliance measures of variables. As emerged (Amar, 2014) if the estimation of the coefficient lies between the -1 to +1 that demonstrates the reinforce relationship between variables. In the event that the coefficient reverence is identically tantamount to or connecting +1 it builds up that there is a determinedly positive relationship transpire between variables. Regardless, inquisitively, if the estimation of the coefficient is equipollent to or close-by - 1 that unequivocally negative or antithesis relationship transpires.

\begin{tabular}{|rl|r|r|r|r|}
\hline & \multicolumn{1}{|c|}{ Table II } \\
\hline \multirow{4}{*}{ BI } & BI & CA & \multicolumn{1}{c|}{ R } & \multicolumn{1}{c|}{ PI } \\
& Pearson Correlation & 1 & $.471^{* *}$ & $.603^{* *}$ & $.393^{* *}$ \\
& Sig. (2-tailed) & & .000 & .000 & .000 \\
& $\mathrm{~N}$ & 230 & 230 & 230 & 230 \\
& Pearson Correlation & $.471^{* *}$ & 1 & $.380^{* *}$ & $.300^{* *}$ \\
& Sig. (2-tailed) & .000 & & .000 & .000 \\
& $\mathrm{~N}$ & 230 & 230 & 230 & 230 \\
& Pearson Correlation & $.603^{* *}$ & $.380^{* *}$ & 1 & $.332^{* *}$ \\
$\mathrm{R}$ & Sig. (2-tailed) & .000 & .000 & .000 \\
& $\mathrm{~N}$ & 230 & 230 & 230 & 230 \\
& Pearson Correlation & $.393^{* *}$ & $.300^{* *}$ & $.332^{* *}$ & 1 \\
PI & .000 & .000 & .000 & \\
& Sig. (2-tailed) & 230 & 230 & 230 & 230 \\
\hline
\end{tabular}

**. Correlation is consequential at the 0.01 level (2-tailed).

The table that exhibited above demonstrates that the sodality amounts of factors with one another.

\subsection{Regression Analysis of Brand image and purchase intentions}

\begin{tabular}{|c|c|c|c|c|}
\hline \multirow{2}{*}{ Typothesis } & predictors & $\mathbf{R}$ & $\mathbf{R}^{\mathbf{2}}$ & $\begin{array}{c}\text { Adjusted } \\
\mathbf{R}^{\mathbf{2}}\end{array}$ \\
\hline $\mathbf{H 1}$ & $\begin{array}{c}\text { Brand image } \\
\text { Purchase } \\
\text { intentions }\end{array}$ & $.393^{\mathrm{a}}$ & .154 & .151 \\
\hline
\end{tabular}

Table IV Coefficients

\begin{tabular}{|c|c|c|c|c|c|c|}
\hline \multicolumn{2}{|c|}{ Hypothesis } & \multicolumn{2}{|c|}{$\begin{array}{c}\text { Unstandardized } \\
\text { Coefficients }\end{array}$} & $\begin{array}{c}\text { Standardized } \\
\text { Coefficients }\end{array}$ & \multirow{2}{*}{$\begin{array}{c}\text { S-value } \\
\text { (p-value) }\end{array}$} \\
\cline { 3 - 6 } \multicolumn{2}{|c|}{} & Beta & Std.Error & Beta & & \\
\hline \multirow{2}{*}{ H1 } & Constant & 3.623 & .316 & & 11.457 & $.000^{* * *}$ \\
\cline { 2 - 7 } & Brand image & .302 & .047 & .393 & 6.449 & $.000^{* * *}$ \\
\hline
\end{tabular}

The model layout exhibits that modification in predictor variable by 1 unit than dependent variable change .393. All things considered if $1 \%$ change occurs in a predictor variable than $15 \%$ change occurs in the dependent variable. These results show the exceedingly rudimental sodality between the dependent and predictor variable. $\mathrm{P}$ esteem is .000 . By and immensely colossal it exhibits that there is constructive relationship that will subsist. The estimation of beta is .393 that is under .4. According to this result H1 will be acknowledged. 


\subsection{Regression Analysis of Brand image and customer attitude}

Table V model summary

\begin{tabular}{|c|c|r|r|c|}
\hline Hypothesis & predictors & $\mathbf{R}$ & $\mathbf{R}^{\mathbf{2}}$ & $\begin{array}{c}\text { Adjusted } \\
\mathbf{R}^{\mathbf{2}}\end{array}$ \\
\hline $\mathbf{H 2}$ & $\begin{array}{c}\text { Brand image } \\
\text { Customer attitude }\end{array}$ & .603 & .364 & .361 \\
\hline
\end{tabular}

Table VI Coefficients

\begin{tabular}{|c|c|c|c|c|c|c|}
\hline \multicolumn{2}{|c|}{ Hypothesis } & \multicolumn{2}{c|}{$\begin{array}{c}\text { Unstandardized } \\
\text { Coefficients }\end{array}$} & $\begin{array}{c}\text { Standardized } \\
\text { Coefficients }\end{array}$ & \multirow{2}{*}{$\begin{array}{c}\text { Sig } \\
\text { (p-value }\end{array}$} \\
\cline { 3 - 7 } \multicolumn{2}{|c|}{} & Beta & Std.Error & Beta & & \\
\hline \multirow{2}{*}{ H2 } & Constant & 5.695 & .810 & & 7.029 & $.000^{* * *}$ \\
\cline { 2 - 7 } & Brand image & 1.371 & .120 & .603 & 11.415 & $.000^{* * *}$ \\
\hline
\end{tabular}

The model outline demonstrates that adjustment in predictor variable by 1 unit than mediate variable change by .603. All things considered, if $1 \%$ change occurs in a predictor variable than $36 \%$ changes transpire in mediate variable. These outcomes demonstrate the prodigiously and sizably voluminous connection subsists. $\mathrm{P}$ value is .000. In general it appears there is noteworthiness moderate construct relationship will subsist. The estimation of $\mathrm{B}$ is .603 that is more prominent than .4. According to this result, $\mathrm{H} 2$ will be acknowledged.

\subsection{Regression Analysis of Customer attitude and purchase intentions}

Table VII model summary

\begin{tabular}{|c|c|c|c|c|}
\hline Hypothesis & predictors & $\mathbf{R}$ & $\mathbf{R}^{\mathbf{2}}$ & $\begin{array}{c}\text { Adjusted } \\
\mathbf{R}^{\mathbf{2}}\end{array}$ \\
\hline $\mathbf{H 3}$ & $\begin{array}{c}\text { Customer attitude } \\
\text { Purchase } \\
\text { intentions }\end{array}$ & $.300^{\mathrm{a}}$ & .090 & .086 \\
\hline
\end{tabular}

Table VIII Coefficients

\begin{tabular}{|c|c|c|c|c|c|c|}
\hline \multicolumn{2}{|c|}{ Hypothesis } & \multicolumn{2}{c|}{$\begin{array}{c}\text { Unstandardized } \\
\text { Coefficients }\end{array}$} & $\begin{array}{c}\text { Standardized } \\
\text { Coefficients }\end{array}$ & t-value & $\begin{array}{c}\text { Sig } \\
\text { (p-value) }\end{array}$ \\
\cline { 3 - 7 } & Beta & Std.Error & Beta & & $.000^{* * *}$ \\
\hline \multirow{3}{*}{$\mathbf{H 3}$} & Constant & 3.832 & .381 & & 10.061 & $.000^{* * *}$ \\
\cline { 2 - 7 } & $\begin{array}{c}\text { Customer } \\
\text { attitude }\end{array}$ & .228 & .048 & .300 & 4.742 & \\
\hline
\end{tabular}

The model outline demonstrates that adjustment in a mediate variable by 1 unit than independent variable change by .300 . In other words if $1 \%$ adjustment take in an intervening variable than $8.6 \%$ change transpires in the dependent variable. These outcomes demonstrate the very critical connection subsists. P value is .000. In general this demonstrates an eminent positive relationship will subsist. The estimation of B is .300 that is under .4 . According to this result, $\mathrm{H} 3$ will be acknowledged.

\subsection{Regression analysis of moderation}

Table IX model summary

\begin{tabular}{|c|c|c|c|c|}
\hline Hypothesis & predictors & $\mathbf{R}$ & $\mathbf{R}^{2}$ & \multicolumn{1}{c|}{$\begin{array}{c}\text { Adjusted } \\
\mathbf{R}^{2}\end{array}$} \\
\hline $\mathbf{H 4}$ & $\stackrel{\text { Brand image } \underset{\mathrm{P}}{\longrightarrow} \text { Purchase intentions }}{\longrightarrow}$ customer attitude & $.490^{\mathrm{a}}$ & .240 & .237 \\
\hline
\end{tabular}




\begin{tabular}{|c|c|c|c|c|c|c|}
\hline \multirow{2}{*}{\multicolumn{2}{|c|}{ Hypothesis }} & \multicolumn{2}{|c|}{$\begin{array}{c}\text { Unstandardized } \\
\text { Coefficients }\end{array}$} & \multirow{2}{*}{$\begin{array}{c}\begin{array}{c}\text { Standardized } \\
\text { Coefficients }\end{array} \\
\text { Beta }\end{array}$} & \multirow[t]{2}{*}{ t-value } & \multirow[t]{2}{*}{$\begin{array}{c}\text { Sig } \\
\text { (p-value) }\end{array}$} \\
\hline & & Beta & Std.Error & & & \\
\hline \multirow[b]{2}{*}{ H4 } & (Constant) & 6.093 & .218 & & 27.968 & .000 \\
\hline & IV_MOD & .016 & .002 & .490 & 8.484 & .000 \\
\hline
\end{tabular}

$* \mathrm{p}<0.05, * * \mathrm{p}<0.01 * * * \mathrm{p}<0.001$

In this B change .393 to .490 . It implicatively insinuates that the moderate variable will be fundamentally decidedly impacted between the independent and the mediate variable. These outcomes demonstrate the exceptionally sizably voluminous outcomes. $p$ value is .000 . By and immensely colossal it demonstrates an impuissant constructive connection will have. The estimation of B is .433 that is more eminent than .4. According to this result, $\mathrm{H} 4$ will be acknowledged

\subsection{Regression analysis of mediation}

Table XI model summary

\begin{tabular}{|c|c|c|c|c|}
\hline Hypothesis & predictors & $\mathbf{R}$ & $\mathbf{R}^{\mathbf{2}}$ & $\begin{array}{c}\text { Adjusted } \\
\mathbf{R}^{\mathbf{2}}\end{array}$ \\
\hline H5 & Brand image $\longrightarrow$ customer attitude & $.393^{\mathrm{a}}$ & .154 & .151 \\
\cline { 3 - 5 } & & $.415^{\mathrm{b}}$ & .172 & .165 \\
\hline
\end{tabular}

Table XII Coefficients

\begin{tabular}{|c|c|c|c|c|c|c|}
\hline \multirow{2}{*}{\multicolumn{2}{|c|}{ Hypothesis }} & \multicolumn{2}{|c|}{$\begin{array}{c}\text { Unstandardized } \\
\text { Coefficients }\end{array}$} & \multirow{2}{*}{$\begin{array}{c}\begin{array}{c}\text { Standardized } \\
\text { Coefficients }\end{array} \\
\text { Beta } \\
\end{array}$} & \multirow[t]{2}{*}{ t-value } & \multirow[t]{2}{*}{$\begin{array}{c}\text { Sig } \\
\text { (p-value) }\end{array}$} \\
\hline & & Beta & Std.Error & & & \\
\hline \multirow[b]{2}{*}{ H5 } & (Constant) & 3.623 & .316 & & 11.457 & .000 \\
\hline & IV & .302 & .047 & .393 & 6.449 & .000 \\
\hline & (Constant) & 3.149 & .381 & & 8.271 & .000 \\
\hline & IV & .248 & .053 & .322 & 4.698 & .000 \\
\hline & mediation & .139 & .063 & .150 & 2.195 & .029 \\
\hline
\end{tabular}

$* \mathrm{p}<0.05, * * \mathrm{p}<0.01 * * * \mathrm{p}<0.001$

The model outline demonstrated that $16.5 \%$ change will transpire in buy prospects because of progress in brand image and customer attitude. The value of consequentiality is 0.029 that demonstrates the eminent connection. The B value will diminish from .393 to .322 . Generally verbalizing outcomes will be demonstrated that intercession has an astronomically immense constructive outcome. As designated by this outcome, H5 will be accepted.

\section{Conclusion and Recommendation}

Present investigation demystifies that how the brand image and customer attitude will influence on the purchase intentions. Supplementally, inspect that how religiosity influences the brand image and customer attitudes. In the subsisting research, the researcher demystifies the connection between brand image and purchase intentions. The regression examination estimating $B$, the esteem is .393 and the $p$ value is .000 . That demonstrates the high consequentiality level. As designated by these outcomes, there is a critical constructive relationship will have between the brand image and purchase intentions? The outcome of subsisting investigation is as expressed in past study (Anak, Sukaatmadja \& Yasa, 2018; Iswara \& Jatra, 2017; Nguyen Minh Hal and Huynh Luong Tam, 2015). This result demonstrates that brand image influences the cull of the customer regarding Islamic banks. So as per this, our 1st notional theorization acknowledged. Moreover, the present examination elucidates the connection between the brand image and customer attitude. Through the factual investigation estimating, B is .603 with the esteem value .000 . As per this result, there is a sizably voluminous constructive relationship will have between the brand image and customer attitude. As it, if the brand image is expanded emphatically than good change transpires in the customer attitude in regards to Islamic banks. The results of the present examination are supplementally identified with past investigations (Aghekyan-Simonian at el., 2012; Nguyen Minh Ha and Huynh Luong Tam, 2015). So as betokened by these contentions, our 2 nd notional theorization will be acknowledged. The following result of the present investigation is about the connection between customer attitude and purchase intentions. The 
$\mathrm{B}$ of factual examination is .300 with the $\mathrm{P}$ value is .000 . These outcomes demonstrate that there is a critical constructive connection between customer attitude and brand image. The results of this investigation is same as past explores (Lim et al., (2017; Solomon et al., 2018). As designated by the overhead discourse, our 3rd theory will likewise be acknowledged. The connection between the brand image and customer attitude demonstrates the constructive and high paramount connection. After the mitigation impact of religiosity, the B will be .490 that is high from .4 with $\mathrm{p}$ value .000 . These outcomes demonstrate that religiosity emphatically directs between the brand image and customer attitude. So the religiosity is a decent arbitrator. This outcome demonstrates that our 4th notional theorization will be acknowledged. The cessation, the last outcomes identified with the middle person. After the intervention investigation, the beta esteem is .322 with critical dimension. As per these outcomes, our last theory will likewise be acknowledged.

The consequences of this investigation are in a general sense rudimental for the financial business (banking sector), explicitly for the Islamic financial area (Islamic banking). It will likewise avail the Islamic banks with having a decent image in the psyche of their customer. In this manner, the present examination simply fixated on Islamic banks. In any case, the result of this examination can likewise valuable for different components or businesses through the inditement survey of this investigation. It has been understandable that expansion in the brand image the attitude of the customer will transmute decidedly and predicated on these purchase intentions will likewise increment. The expansion in the purchase intentions is progressively gainful for the businesses. In Pakistan, the Islamic financial area has no much famous. Since individuals have very little comprehended the fundamental goals of Islamic banks and furthermore they have no data cognate to distinction of Islamic financial framework and conventional financial framework. That is rudimental for supervisors to make a decent brand image of Islamic banks through the showcasing procedures. The present examination will be simply led in the Islamic banks of southern Punjab Pakistan. To commence with, course for future research is directing a homogeneous report in an alternate territory or the distinctive business segment. Second, more variable will be utilized that transmute the customer attitude towards purchase intentions like the quantification of data about Islamic banks; nature of administrations may transmute the customer attitude towards the purchase intentions.

\section{Reference}

Amin, H., Abdul Rahman, A. R., Abdul Razak, D., \& Rizal, H. (2017). Consumer attitude and preference in the Islamic mortgage sector: a study of Malaysian consumers. Management Research Review, 40(1), 95-115.

Amin, H., Rahim Abdul Rahman, A., LaisonSondohJr, S., \& Magdalene ChooiHwa, A. (2011). Determinants of customers' intention to use Islamic personal financing: The case of Malaysian Islamic banks. Journal of Islamic Accounting and Business Research, 2(1), 22-42.

An, D., \& Kim, S. (2007). Relating Hofstede's masculinity dimension to gender role portrayals in advertising: A cross-cultural comparison of web advertisements. International Marketing Review, 24(2), 181-207.

Arista, E. D., \&Astuti, S. R. T. (2012). Analisispengaruhiklan, kepercayaanmerek, dancitramerekterhadapminatbelikonsumen. JurnalIlmuEkonomi ASET, 13(1).

Andrianto, H. N., \&Idris, I. (2013). PengaruhKualitasProduk, Citra Merek, Harga Dan PromosiTerhadapKeputusanPembelian Mobil JenisMpvMerek Toyota KijangInnova Di Semarang (Doctoral dissertation, FakultasEkonomikadanBisnis).

Bhuian, S. N., Sharma, S. K., Butt, I., \& Ahmed, Z. U. (2018). Antecedents and pro-environmental consumer behavior (PECB): the moderating role of religiosity. Journal of Consumer Marketing, (just-accepted), 00-00.

Eid, R., \& El-Gohary, H. (2015). The role of Islamic religiosity on the relationship between perceived value and tourist satisfaction. Tourism Management, 46, 477-488.

Fishbein, M., \&Ajzen, I. (1975). Belief, attitude, intention, and behavior: An introduction to theory and research.

Huang, J. H., Lee, B. C., \&Hsun Ho, S. (2004). Consumer attitude toward gray market goods. International Marketing Review, 21(6), 598-614.

Iswara, I. G. A. D., \&Jatra, I. M. Peran Brand Image DalamMemediasiPengaruh Electronic Word of Mouth Terhadap Purchase Intention. E-JurnalManajemenUniversitasUdayana, 6(8).

Ismail, S., Haron, H., Ismail, I., \&Vinten, G. (2007). Factors Influencing Auditors' Acceptance of the Practice Review System. Asian Academy of Management Journal of Accounting and Finance, 12(2), 57-82.

Johnson, B. R., Jang, S. J., Larson, D. B., \& De Li, S. (2001). Does adolescent religious commitment matter? A reexamination of the effects of religiosity on delinquency. Journal of Research in Crime and Delinquency, 38(1), 22-44.

Kottler, P., \& Armstrong, G. (2008). Prinsip-PrinsipPemasaran (Edisi ke-12. Jilid ke-1). Jakarta: Erlangga.

Koenig, H. G., McCullough, M. E., \& Larson, D. B. (2001). Handbook of religion and health. New York, NY, US: Oxford University Press.

Lee, B. C. (2012). The determinants of consumer attitude toward service innovation-the evidence of ETC system in Taiwan. Journal of Services Marketing, 26(1), 9-19.

Mansoor Khan, M. (2008). Main features of the interest-free banking movement in Pakistan (1980- 
2006). Managerial Finance, 34(9), 660-674.

Mohammadian, M. (2010). Ronaghi, Mohammad Hosein.". Brand Promotion Strategies and Techniques.

Morwitz, V. G., Steckel, J. H., \& Gupta, A. (2007). When do purchase intentions predict sales? International Journal of Forecasting, 23(3), 347-364.

Nguyen, V. P., \& Tran, T. T. (2013). Modeling of Determinants Influence in Consumer Behavior towards Counterfeit Fashion Products. Business Management Dynamics, 2(12), 12-23.

Phau, I., Teah, M., \& Lee, A. (2009). Targeting buyers of counterfeits of luxury brands: A study on attitudes of Singaporean consumers. Journal of Targeting, Measurement, and Analysis for Marketing, 17(1), 3-15.

Shah, B. A., Niazi, G. S. K., \&Majid, A. (2016). Employees' Perceptions about Islamic Banking and its Growth Potential in Pakistan. Business \& Economic Review, 8(1), 53-76.

Shukla, P. (2011). Impact of interpersonal influences, brand origin and brand image on luxury purchase intentions: Measuring interfunctional interactions and a cross-national comparison. Journal of world business, 46(2), 242-252.

Sun, S., \& Wang, Y. (2010). Familiarity, beliefs, attitudes, and consumer responses toward online advertising in China and the United States. Journal of Global Marketing, 23(2), 127-138.

Schiffman, L. G., \&Kanuk, L. L. (2010). Consumer Behavior, Wisconsin Prentice Hall International. Inc. Sherman, $S P$ (1985).

Worthington Jr, E. L., Wade, N. G., Hight, T. L., Ripley, J. S., McCullough, M. E., Berry, J. W., ... \&O'connor, L. (2003). The Religious Commitment Inventory--10: Development, refinement, and validation of a brief scale for research and counseling. Journal of Counseling Psychology, 50(1), 84.

Wilson, R. (2002). The evolution of the Islamic financial system. Islamic Finance, Innovation and Growth, Euromoney books and AAOIFI (London). Yacuby, (2006).

Wijaya, B. S. (2013). Dimensions of brand image: a conceptual review from the perspective of brand communication. European Journal of Business and Management, 5(31).

Xu, Y., Summers, T. A., \& Belleau, B. D. (2004). Who buys American alligator?: Predicting purchase intention of a controversial product. Journal of Business Research, 57(10), 1189-1198. 